\title{
A systematic review and meta-analysis of clinical trials investigating the effects of flaxseed supplementation on plasma C-reactive protein concentrations
}

\author{
Sorin Ursoniu ${ }^{1}$, Amirhossein Sahebkar², Maria-Corina Serban ${ }^{3}$, Iulia Pinzaru ${ }^{4}$, Cristina Dehelean ${ }^{5}$, \\ Lavinia Noveanu ${ }^{3}$, Jacek Rysz ${ }^{6}$, Maciej Banach ${ }^{6}$; Lipid and Blood Pressure Meta-Analysis \\ Collaboration (LBPMC) Group
}

\author{
'Department of Functional Sciences, Discipline of Public Health, "Victor Babes" \\ University of Medicine and Pharmacy, Timisoara, Romania \\ ${ }^{2}$ Biotechnology Research Centre, Mashhad University of Medical Sciences, Mashhad, \\ Iran \\ 'Department of Functional Sciences, Discipline of Pathophysiology, "Victor Babes" \\ University of Medicine and Pharmacy, Timisoara, Romania \\ ${ }^{4}$ Department 2, Discipline of Toxicology, "Victor Babes" University of Medicine and \\ Pharmacy, Timisoara, Romania \\ ${ }^{5}$ Department of Toxicology, "Victor Babes" University of Medicine and Pharmacy, \\ Timisoara, Romania \\ ${ }^{6}$ Department of Hypertension, Chair of Nephrology and Hypertension, Medical \\ University of Lodz, Lodz, Poland
}

Submitted: 16 May 2017

Accepted: 28 May 2017

Arch Med Sci 2019; 15, 1: 12-22

DOI: https://doi.org/10.5114/aoms.2018.81034

Copyright $\odot 2018$ Termedia \& Banach

\section{Abstract}

Introduction: Many experimental and clinical trials have suggested that flaxseed might be a potent antihypertensive, but the evidence concerning the effects of flaxseed supplements on plasma C-reactive protein (CRP) concentrations has not been fully conclusive. We assessed the impact of the effects of flaxseed supplementation on plasma CRP concentrations through a systematic review of literature and meta-analysis of available randomised controlled trials (RCTs). Material and methods: The literature search included EMBASE, ProQuest, CINAHL, and PUBMED databases up to $1^{\text {st }}$ February 2016 to identify RCTs investigating the effect of flaxseed supplements on plasma CRP concentrations. Meta-analysis was performed using a random-effects model, and effect size was expressed as weighed mean difference (WMD) and 95\% confidence interval $(\mathrm{Cl})$.

Results: Meta-analysis of 17 selected RCTs with 1256 individuals did not suggest a significant change in plasma CRP concentrations following supplementation with flaxseed-containing products (WMD: $-0.25 \mathrm{mg} / \mathrm{l}, 95 \% \mathrm{Cl}$ : $-0.53,0.02, p=0.074)$. The effect size was robust in the leave-one-out sensitivity analysis. Subgroup analysis did not suggest any significant difference in terms of changing plasma CRP concentrations among different types of flaxseed supplements used in the included studies, i.e. flaxseed oil (WMD: $-0.67 \mathrm{mg} / \mathrm{l}, 95 \% \mathrm{Cl}:-2.00,0.65, p=0.320$ ), lignan extract (WMD: $-0.32 \mathrm{mg} / \mathrm{l}$, $95 \% \mathrm{Cl}:-0.71,0.06, p=0.103$ ) and ground powder (WMD: $-0.18 \mathrm{mg} / \mathrm{l}$, $95 \% \mathrm{Cl}:-0.42,0.06, p=0.142)$.

Conclusions: The meta-analysis of RCTs did not show a significant change in plasma CRP concentrations following supplementation with various flaxseed products. Large, well-designed studies should be still performed to validate the current results.

Key words: flaxseed, linseed, Linum usitatissimum, C-reactive protein, meta-analysis, systematic review.

\section{Corresponding author:} Prof. Maciej Banach MD, PhD, FNLA, FAHA, FESC, FASA Department of Hypertension WAM University Hospital Medical University of Lodz 113 Zeromskiego St 90-549 Lodz, Poland Phone: +48 426393771 Fax: +48 426393771 E-mail: maciejbanach@aol. co.uk 


\section{Introduction}

Flaxseed (Linum usitatissiumum) is one of the most consistent sources in bioactive compounds such as polyunsaturated fatty acid, fibres, proteins, antioxidants, and lignans [1]. The translation of the Latin origin of the name, meaning "very useful", is suggestive, considering the various products with biological effects that contain flaxseed and its fractions: flaxseed oil, whole seed, flaxseed meal, flaxseed mucilage and/or alcohol extracts, flaxseed hulls, ground whole seed, and flaxseed oleosomes [2]. Two major varieties of flaxseed products are available, but with different biological activity $[1,3]$. Flaxseed contains onethird soluble and two-thirds insoluble fibres from a total of $35-45 \%$ of fibres. It also contains a high amount of $\alpha$-linolenic acid, an essential fatty acid that cannot be synthesised by the human body [4]. Other biologically important compounds found in flaxseed products are linoleic acid, linolenic acid, alkaloids, cyclic peptides, lignans, polysaccharides, cyanogenic glycosides, and cadmium [2]. These compounds have remarkable antioxidant, hypotensive, anti-inflammatory, and hypoglycaemic activities [5, 6], being used for prevention of rheumatoid arthritis, cardiovascular (CV) diseases, and asthma [7-10].

A number of factors such as tumour necrosis factor (TNF), pro-inflammatory cytokines, and interleukins (IL) are responsible for increased levels of C-reactive protein (CRP), an important marker of systemic inflammation [11]. C-recative protein is also considered as a strong predictor of $\mathrm{CV}$ risk in comparison to several other inflammatory markers $[12,13]$. Some studies suggest that this acute-phase protein marker, synthesised by the adipose tissue or by the liver, might be significantly influenced by the administration or consumption of different formulations of flaxseed, like flaxseed oil, flaxseed lignan, or flaxseed supplementation [14]. Therefore, the aim of the present study is to review available randomised clinical trials (RCTs) involving the use of different forms of flaxseed to evaluate their effectiveness on the CRP plasma concentration.

\section{Material and methods}

\section{Search strategy}

This study was designed according to the guidelines of the 2009 preferred reporting items for systematic reviews and meta-analysis (PRISMA) statement [15]. EMBASE, ProQuest, CINAHL, and PUBMED databases were searched using the following search terms in titles and $a b$ stracts: ("linseed" OR "flax seed" OR "flaxseed" OR "linseed meal" OR "linum usitatissimum") AND ("c reactive protein" OR "c reaction protein" OR "c-reactive protein" OR CRP OR "protein c re- active" OR "serum c reactive protein"). The wildcard term " "*" was used to increase the sensitivity of the search strategy. The search was limited to studies in humans published in English. The literature was searched until $1^{\text {st }}$ February 2016. Two reviewers (SU and $\mathrm{M}-\mathrm{CS}$ ) evaluated each article independently, carried out data extraction and quality assessment. Disagreements were resolved by discussion with a third party (MB).

\section{Study selection}

Original studies were included if they met the following inclusion criteria: (i) clinical trials with a case-control or cross-over design, (ii) investigation of the effect of flaxseed preparations on plasma CRP concentrations, (iii) providing baseline and end-trial plasma CRP concentrations in both flaxseed and control groups, and (iv) having a supplementation with flaxseed for at least 2 weeks.

Non-clinical studies, uncontrolled trials, and trials with insufficient data on CRP values in flaxseed and control groups were excluded from the meta-analysis.

\section{Data extraction}

Eligible studies were reviewed, and the following data were abstracted: 1) first author's name; 2) year of publication; 3) country were the study was performed; 4) study design; 5) number of participants in the flaxseed and control groups; 6) intervention assigned to the control group; 7) type (lignan extract, ground powder, or oil) and dose of flaxseed supplement; 8) treatment duration; 9) age, gender, and body mass index (BMI) of study participants; 10) systolic and diastolic blood pressures; and 11) data regarding baseline and follow-up concentrations of CRP. Data extraction was performed independently by two reviewers; disagreements were resolved by a third reviewer.

\section{Quality assessment}

Assessment of risk of bias in the studies included in the analysis was performed systematically using the Cochrane quality assessment tool for RCTs [16]. The Cochrane tool has seven criteria for quality assessment: random sequence generation (selection bias), allocation sequence concealment (selection bias), blinding of participants and personnel (performance bias), blinding of outcome assessment (detection bias), incomplete outcome data (attrition bias), selective outcome reporting (reporting bias), and other potential sources of bias. The risk of bias in each study was judged to be low, high, or unclear. Risk-of-bias assessment was performed independently by two reviewers; disagreements were resolved by a third reviewer. 


\section{Quantitative data synthesis}

Meta-analysis was conducted using Comprehensive Meta-Analysis (CMA) V2 software (Biostat, NJ) [17]. Net changes in measurements (change scores) were calculated as follows: measure at end of follow-up - measure at baseline. For single-arm, cross-over trials, the net change in plasma concentrations of CRP were calculated by subtracting the value after control intervention from that reported after treatment. All values were collated as mg/l. Standard deviations (SDs) of the mean difference were calculated using the following formula: $S D=$ square root $\left[\left(S_{\text {pre-treatment }}\right)^{2}+\right.$ $\left.\left(\mathrm{SD}_{\text {post-treatment }}\right)^{2}-\left(2 \mathrm{R} \times \mathrm{SD}_{\text {pre-treatment }} \times \mathrm{SD}_{\text {post-treatment }}\right)\right]$, assuming a correlation coefficient (R) equal to 0.5 . If the outcome measures were reported in median and range (or 95\% confidence interval $(\mathrm{Cl})$ ), mean and standard SD values were estimated using the method described by Wan et al. [18] Where standard error of the mean (SEM) only was reported, the standard deviation (SD) was estimated using the following formula: SD = SEM $\times$ sqrt $(n)$, where $n$ is the number of subjects.

Net changes in measurements (change scores) were calculated for parallel and cross-over trials, as follows: (measure at the end of follow-up in the treatment group - measure at baseline in the treatment group) - (measure at the end of follow-up in the control group - measure at baseline in the control group). A random-effects model (using DerSimonian-Laird method) and the generic inverse variance method were used to compensate for the heterogeneity of studies in terms of study design, treatment duration, and the characteristics of populations being studied [19]. Inter-study

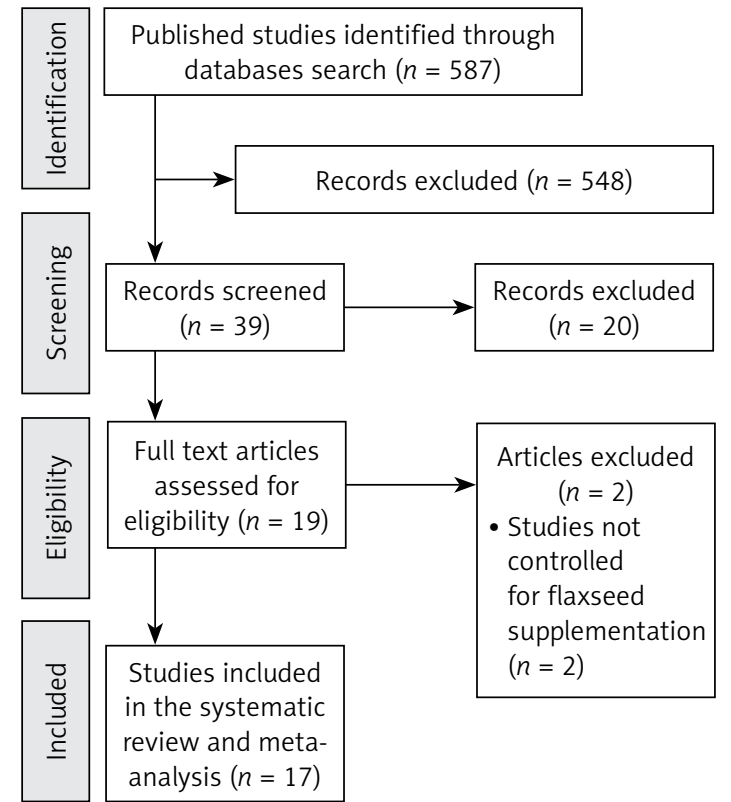

Figure 1. Flow chart of the number of studies identified and included into the meta-analysis heterogeneity was assessed using Cochran Q test and $l^{2}$ index. In order to evaluate the influence of each study on the overall effect size, sensitivity analysis was conducted using the leave-one-out method, i.e. iteratively removing one study each time and repeating the analysis.

\section{Meta-regression}

A weighted random-effects meta-regression using an unrestricted maximum likelihood model was performed to assess the association between the overall estimate of effect size with potential moderator variables, including dose and duration of supplementation with flaxseed.

\section{Publication bias}

Potential publication bias was explored using visual inspection of Begg's funnel plot asymmetry, and Begg's rank correlation and Egger's weighted regression tests. The Duval and Tweedie "trim and fill" method was used to adjust the analysis for the effects of publication bias [20].

\section{Results}

\section{Search results and trial flow}

The initial screening comprised 587 full text articles, and we removed the articles with titles that were obviously irrelevant. Selected articles were hand searched to identify further relevant studies. Among 19 full text articles assessed for eligibility, two studies were excluded, being not controlled for flaxseed supplementation (Figure 1). After final assessment, 17 eligible trials achieved the inclusion criteria and were preferred for the final meta-analysis [7, 21-36].

\section{Characteristics of included studies}

In total, 1256 individuals were included to the meta-analysis, 639 participants were allocated to the flaxseed supplementation group and 617 to the control group. The number of participants in the analysed studies ranged from nine to 85 in the flaxseed group and from eight to 94 in the control group. The included studies were published between 2007 and 2015, and were conducted in the USA $(n=5)$, Brazil $(n=4)$, Canada $(n=3)$, China $(n=2)$, Greece, Denmark, and Iran. The following flaxseed supplementation was administered in the included trials: ground powder $13 \mathrm{~g}$ to $60 \mathrm{~g} / \mathrm{day}$ (2.9 g to $10 \mathrm{~g} \mathrm{ALA}$ /day), oil containing $1.022 \mathrm{~g}$ to $8 \mathrm{~g} \mathrm{ALA} /$ day, and derived lignan complex $360 \mathrm{mg}$ to $600 \mathrm{mg}$ total SDG/day. Duration of flaxseed supplementation ranged between 2 weeks and 12 months. Ten trials were designed as a parallel group and seven as crossover studies. Table I shows the demographic characteristics and baseline pa- 


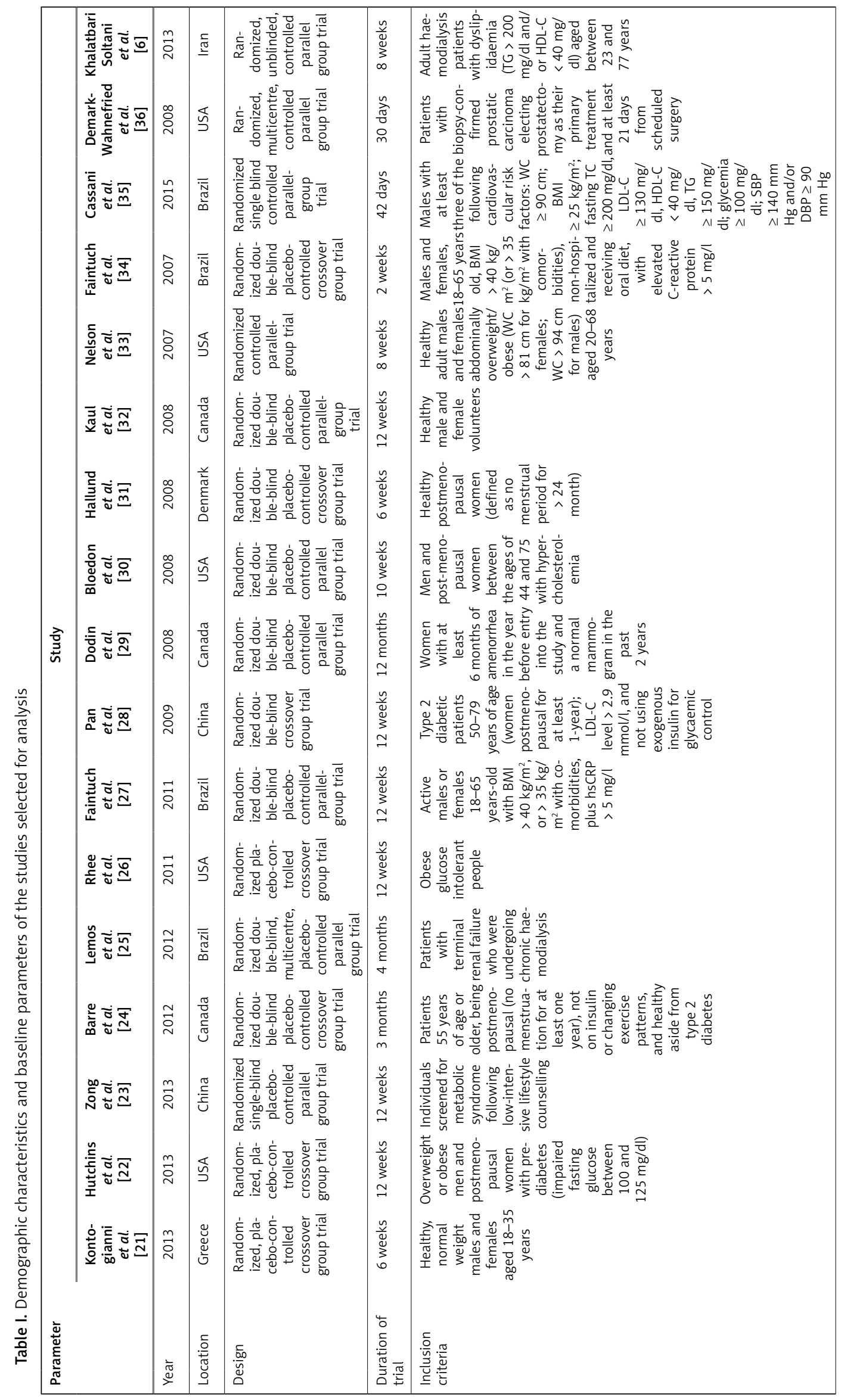




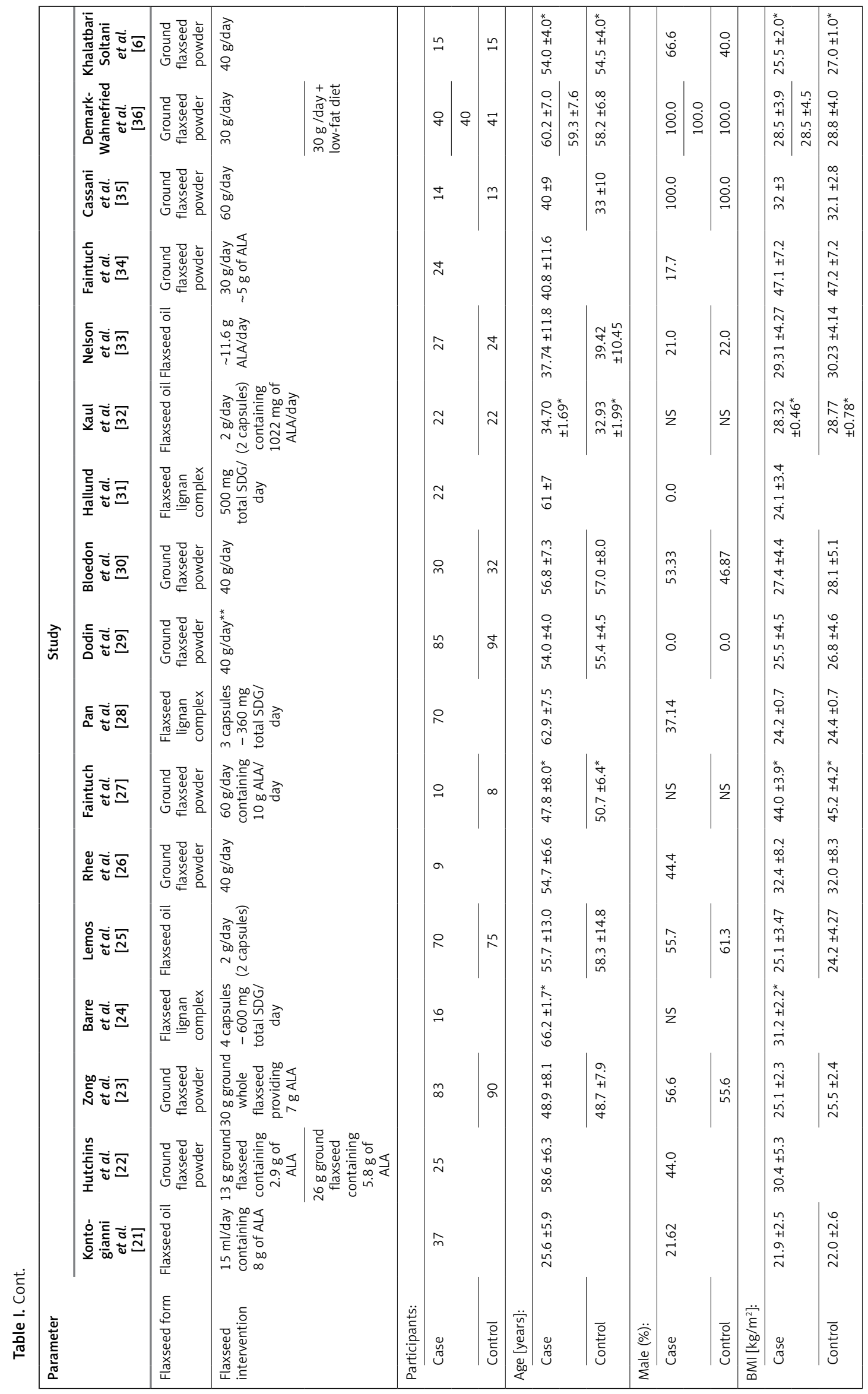




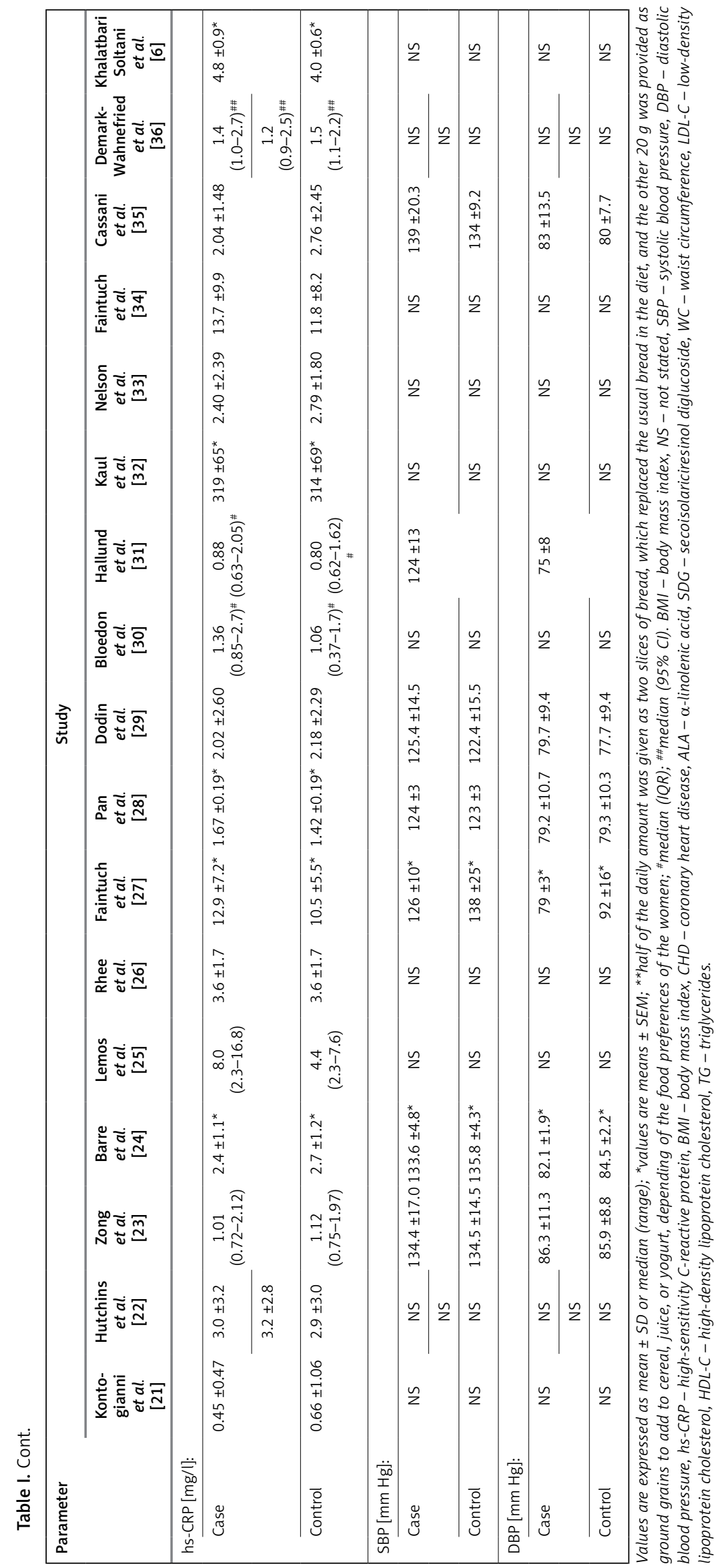


S. Ursoniu, A. Sahebkar, M.C. Serban, I. Pinzaru, C. Dehelean, L. Noveanu, J. Rysz, M. Banach; Lipid and Blood Pressure Meta-Analysis Collaboration (LBPMC) Group

rameters of the included studies. No adverse events related to the supplementation were reported.

\section{Risk of bias assessment}

An unclear risk of bias with respect to sequence generation and allocation concealment was observed. Some trials were not blinded, but studies were low risk in terms of other sources of bias. The systematic assessment of bias in the included studies is shown in Table II.

\section{Effect of flaxseed supplementation on plasma CRP concentrations}

Meta-analysis of data from 17 trials did not suggest a significant change in plasma CRP con- centrations following supplementation with flaxseed-containing products (WMD: $-0.25 \mathrm{mg} / \mathrm{l}$, 95\% Cl: $-0.53,0.02, p=0.074 ; Q=46.33, P^{2}=$ $61.15 \%$ ) (Figure $2 \mathrm{~A}$ ). The effect size was robust in the leave-one-out sensitivity analysis (Figure 2 B). Subgroup analysis did not suggest any significant difference in terms of changing plasma CRP concentrations among different types of flaxseed supplements used in the included studies, i.e. flaxseed oil (WMD: $-0.67 \mathrm{mg} / \mathrm{l}, 95 \%$ $\left.\mathrm{Cl}:-2.00,0.65, p=0.32 ; Q=28.63, I^{2}=82.54 \%\right)$ (Figure $3 \mathrm{~A}$ ), lignan extract (WMD: $-0.32 \mathrm{mg} / \mathrm{l}$, 95\% Cl: $-0.71,0.06, p=0.103 ; Q=0.02, l^{2}=$ $0 \%$ ) (Figure $3 \mathrm{~B}$ ), and ground powder (WMD: $-0.18 \mathrm{mg} / \mathrm{l}, 95 \% \mathrm{Cl}:-0.42,0.06, p=0.142$ $Q=13.44, I^{2}=33.06 \%$ ) (Figure $3 C$ ).

Table II. Assessment of risk of bias in the included studies using Cochrane criteria

\begin{tabular}{|c|c|c|c|c|c|c|c|}
\hline Study & $\begin{array}{l}\text { Sequence } \\
\text { generation }\end{array}$ & $\begin{array}{l}\text { Allocation } \\
\text { conceal- } \\
\text { ment }\end{array}$ & $\begin{array}{l}\text { Blinding } \\
\text { of partici- } \\
\text { pants and } \\
\text { personnel }\end{array}$ & $\begin{array}{l}\text { Blinding } \\
\text { of outcome } \\
\text { assessment }\end{array}$ & $\begin{array}{c}\text { Incomplete } \\
\text { outcome } \\
\text { data }\end{array}$ & $\begin{array}{l}\text { Selective } \\
\text { outcome } \\
\text { reporting }\end{array}$ & $\begin{array}{c}\text { Other } \\
\text { potential } \\
\text { threats to } \\
\text { validity }\end{array}$ \\
\hline $\begin{array}{l}\text { Kontogianni et al. } \\
2013 \text { [21] }\end{array}$ & U & $U$ & $\mathrm{H}$ & $\mathrm{L}$ & $\mathrm{L}$ & L & $L$ \\
\hline $\begin{array}{l}\text { Hutchins et al. } \\
2013 \text { [22] }\end{array}$ & U & $U$ & $\mathrm{H}$ & $L$ & L & $\mathrm{L}$ & $L$ \\
\hline $\begin{array}{l}\text { Zong et al. } \\
2013 \text { [23] }\end{array}$ & U & U & $\mathrm{H}$ & L & $\mathrm{L}$ & $\mathrm{L}$ & L \\
\hline $\begin{array}{l}\text { Barre et al. } \\
2012[24]\end{array}$ & U & $U$ & L & L & L & L & $L$ \\
\hline $\begin{array}{l}\text { Lemos et al. } \\
2012 \text { [25] }\end{array}$ & U & U & L & L & L & L & $\mathrm{L}$ \\
\hline $\begin{array}{l}\text { Rhee et al. } \\
2011 \text { [26] }\end{array}$ & $U$ & U & $\mathrm{H}$ & L & L & L & $L$ \\
\hline $\begin{array}{l}\text { Faintuch et al. } \\
2011 \text { [27] }\end{array}$ & U & U & L & L & L & L & $L$ \\
\hline $\begin{array}{l}\text { Pan et al. } \\
2009 \text { [28] }\end{array}$ & $\mathrm{L}$ & $L$ & L & $\mathrm{L}$ & L & $L$ & $L$ \\
\hline $\begin{array}{l}\text { Dodin et al. } \\
2008 \text { [29] }\end{array}$ & $\mathrm{L}$ & $L$ & L & $\mathrm{L}$ & $\mathrm{L}$ & $L$ & $L$ \\
\hline $\begin{array}{l}\text { Bloedon et al. } \\
2008 \text { [30] }\end{array}$ & U & U & L & $\mathrm{L}$ & L & L & $L$ \\
\hline $\begin{array}{l}\text { Hallund et al. } \\
2008[31]\end{array}$ & U & U & L & $\mathrm{L}$ & L & L & $L$ \\
\hline $\begin{array}{l}\text { Kaul et al. } \\
2008 \text { [32] }\end{array}$ & $\mathrm{L}$ & $L$ & $L$ & $L$ & $\mathrm{~L}$ & L & $L$ \\
\hline $\begin{array}{l}\text { Nelson et al. } \\
2007 \text { [33] }\end{array}$ & $U$ & $U$ & $\mathrm{H}$ & $\mathrm{H}$ & $L$ & $\mathrm{~L}$ & $L$ \\
\hline $\begin{array}{l}\text { Faintuch et al. } \\
2007 \text { [34] }\end{array}$ & $U$ & $U$ & $L$ & $L$ & L & L & $L$ \\
\hline $\begin{array}{l}\text { Cassani et al. } \\
2015 \text { [35] }\end{array}$ & U & U & $U$ & $U$ & L & L & $L$ \\
\hline $\begin{array}{l}\text { Demark- } \\
\text { Wahnefried et al. } \\
2008 \text { [36] }\end{array}$ & $L$ & $\mathrm{~L}$ & $\mathrm{H}$ & $L$ & L & L & $L$ \\
\hline $\begin{array}{l}\text { Khalatbari Soltani } \\
\text { et al. } 2013 \text { [6] }\end{array}$ & U & U & $\mathrm{H}$ & U & $\mathrm{L}$ & L & $\mathrm{L}$ \\
\hline
\end{tabular}

$L$ - low risk of bias, $H$ - high risk of bias, $U$ - unclear risk of bias. 
A

\begin{tabular}{|c|c|c|c|c|c|c|}
\hline \multirow[t]{2}{*}{ Study name } & \multicolumn{6}{|c|}{ Statistcs for each study } \\
\hline & $\begin{array}{l}\text { Difference } \\
\text { in means }\end{array}$ & $\begin{array}{l}\text { Standard } \\
\text { error }\end{array}$ & & $\begin{array}{l}\text { Lower } \\
\text { limit }\end{array}$ & $\begin{array}{l}\text { Upper } \\
\text { limit }\end{array}$ & $Z$-value $F$ \\
\hline $\begin{array}{l}\text { Kontogianni et al., } 2013 \\
\text { Hutchins et al., } 2013 \mathrm{a} \\
\text { Hutchins et at. } 2013 \mathrm{~b} \\
\text { Zong et at., } 2013 \\
\text { Barre et al., } 2012 \\
\text { Lemos et at., } 2012 \\
\text { Rhee et at., } 2011 \\
\text { Faintuch et al., } 2011 \\
\text { Pan et al., 2009 } \\
\text { Dodin et at., } 2008 \\
\text { Bloedeon et at., } 2008 \\
\text { Hallund et at., } 2008 \\
\text { Kaul et at.., } 2008 \\
\text { Nelson et al., } 2007 \\
\text { Faintuch et al., } 2007 \\
\text { Cassani et at., 2015 } \\
\text { Demark-Wahnefried et al., 2008a } \\
\text { Demark-Wahnefried et al.,2008b } \\
\text { Khelatbari Soltani et at., 2013 }\end{array}$ & $\begin{array}{c}0.450 \\
-0.700 \\
-1.500 \\
0.000 \\
-0.500 \\
-5.930 \\
-2.300 \\
-10.400 \\
-0.310 \\
-0.090 \\
-0.440 \\
-0.330 \\
1.190 \\
0.230 \\
-2.700 \\
-0.240 \\
0.000 \\
-0.530 \\
-3.400 \\
-0.251\end{array}$ & $\begin{array}{l}0.198 \\
1.113 \\
1.078 \\
0.032 \\
1.503 \\
1.264 \\
1.895 \\
15.285 \\
0.308 \\
0.265 \\
0.297 \\
0.265 \\
1.561 \\
0.642 \\
2.307 \\
0.568 \\
0.231 \\
0.286 \\
1.612 \\
0.140\end{array}$ & $\begin{array}{l}0.039 \\
1.238 \\
1.162 \\
0.001 \\
2.260 \\
1.598 \\
3.590 \\
233.632 \\
0.095 \\
0.070 \\
0.088 \\
0.070 \\
2.436 \\
0.412 \\
5.323 \\
0.322 \\
0.054 \\
0.082 \\
2.599 \\
0.020\end{array}$ & $\begin{array}{l}0.063 \\
-2.881 \\
-3.613 \\
-0.062 \\
-3.446 \\
-8.408 \\
-6.014 \\
-40.358 \\
-0.913 \\
-0.609 \\
-1.022 \\
-0.850 \\
-1.869 \\
-1.029 \\
-7.222 \\
-1.353 \\
-0.453 \\
-1.090 \\
-6.560 \\
-0.526\end{array}$ & $\begin{array}{c}0.837 \\
1.481 \\
0.613 \\
0.062 \\
2.446 \\
-3.452 \\
1.414 \\
19.558 \\
0.293 \\
0.429 \\
0.142 \\
0.190 \\
4.249 \\
1.489 \\
1.822 \\
0.873 \\
0.453 \\
0.030 \\
-0.240 \\
0.024\end{array}$ & $\begin{array}{c}2.278 \\
-0.629 \\
-1.391 \\
0.000 \\
-0.333 \\
-4.691 \\
-1.214 \\
-0.680 \\
-1.008 \\
-0.340 \\
-1.482 \\
-1.245 \\
0.762 \\
0.358 \\
-1.170 \\
-0.423 \\
0.000 \\
-1.855 \\
-2.109 \\
-1.786\end{array}$ \\
\hline
\end{tabular}

B

\begin{tabular}{|c|c|c|c|c|c|c|c|c|}
\hline \multirow[t]{2}{*}{ Study name } & \multicolumn{7}{|c|}{ Statistics with study removed } & \multirow{2}{*}{$\begin{array}{c}\text { Difference in means }(95 \% \mathrm{Cl}) \\
\text { with study removed }\end{array}$} \\
\hline & Point & $\begin{array}{l}\text { Standard } \\
\text { error }\end{array}$ & Variance & $\begin{array}{l}\text { Lower } \\
\text { limit }\end{array}$ & $\begin{array}{l}\text { Upper } \\
\text { limit }\end{array}$ & Z-value & $P$-value & \\
\hline $\begin{array}{l}\text { Kontogianni et al., } 2013 \\
\text { Hutchins et al., 2013a } \\
\text { Hutchins et al., 2013b } \\
\text { Zong et al., } 2013 \\
\text { Barre et al., } 2012 \\
\text { Lemos et al., } 2012 \\
\text { Rhee et al., 2011 } \\
\text { Faintuch et al., } 2011 \\
\text { Pan et al., 2009 } \\
\text { Dodin et al., } 2008 \\
\text { Bloedeon et al., } 2008 \\
\text { Hallund et al., } 2008 \\
\text { Kaul et al., } 2008 \\
\text { Nelson et al., } 2007 \\
\text { Faintuch et al., } 2007 \\
\text { Cassani et al., 2015 } \\
\text { Demark-Wahnefried et al., 2008a } \\
\text { Demark-Wahnefried et al., 2008b } \\
\text { Khalatbari Soltani et al., 2013 }\end{array}$ & $\begin{array}{l}-0.349 \\
-0.247 \\
-0.229 \\
-0.374 \\
-0.252 \\
-0.119 \\
-0.239 \\
-0.252 \\
-0.255 \\
-0.285 \\
-0.238 \\
-0.253 \\
-0.264 \\
-0.274 \\
-0.241 \\
-0.257 \\
-0.302 \\
-0.224 \\
-0.218 \\
-0.251\end{array}$ & $\begin{array}{l}0.152 \\
0.143 \\
0.140 \\
0.191 \\
0.143 \\
0.097 \\
0.140 \\
0.141 \\
0.152 \\
0.156 \\
0.150 \\
0.153 \\
0.142 \\
0.145 \\
0.140 \\
0.146 \\
0.158 \\
0.149 \\
0.136 \\
0.140\end{array}$ & $\begin{array}{l}0.023 \\
0.020 \\
0.020 \\
0.037 \\
0.020 \\
0.009 \\
0.020 \\
0.020 \\
0.023 \\
0.024 \\
0.023 \\
0.023 \\
0.020 \\
0.021 \\
0.020 \\
0.021 \\
0.025 \\
0.022 \\
0.018 \\
0.020\end{array}$ & $\begin{array}{l}-0.647 \\
-0.527 \\
-0.505 \\
-0.749 \\
-0.531 \\
-0.310 \\
-0.513 \\
-0.529 \\
-0.552 \\
-0.590 \\
-0.532 \\
-0.554 \\
-0.542 \\
-0.559 \\
-0.516 \\
-0.543 \\
-0.613 \\
-0.515 \\
-0.484 \\
-0.526\end{array}$ & $\begin{array}{l}-0.051 \\
0.033 \\
0.046 \\
0.001 \\
0.028 \\
0.071 \\
0.036 \\
0.025 \\
0.042 \\
0.020 \\
0.056 \\
0.047 \\
0.014 \\
0.011 \\
0.034 \\
0.030 \\
0.009 \\
0.067 \\
0.047 \\
0.024\end{array}$ & $\begin{array}{l}-2.294 \\
-1.729 \\
-1.634 \\
-1.953 \\
-1.767 \\
-1.229 \\
-1.703 \\
-1.781 \\
-1.680 \\
-1.831 \\
-1.585 \\
-1.655 \\
-1.860 \\
-1.885 \\
-1.719 \\
-1.755 \\
-1.906 \\
-1.509 \\
-1.610 \\
-1.786\end{array}$ & $\begin{array}{l}0.022 \\
0.084 \\
0.102 \\
0.051 \\
0.077 \\
0.219 \\
0.089 \\
0.075 \\
0.093 \\
0.067 \\
0.113 \\
0.098 \\
0.063 \\
0.059 \\
0.086 \\
0.079 \\
0.057 \\
0.131 \\
0.107 \\
0.074\end{array}$ & \\
\hline & & & & & & & & -1 \\
\hline
\end{tabular}

Figure 2. Forest plot displaying weighted mean difference and $95 \%$ confidence intervals for the impact of flaxseed supplementation on plasma C-reactive protein concentrations. Lower plot shows leave-one-out sensitivity analysis

\section{Meta-regression}

Meta-regression analysis was conducted to evaluate the association between changes in plasma CRP concentrations and potential confounders, including duration of supplementation with flaxseed and changes in plasma LDL-C concentrations. No significant association was found between changes in plasma CRP levels with either supplementation duration (slope: $-0.001 ; 95 \% \mathrm{Cl}$ : -0.02 to $0.02 ; p=0.928$ ) or plasma LDL-C changes (slope: $0.05 ; 95 \% \mathrm{Cl}:-0.01$ to $0.12 ; p=0.095$ ) (Figure 4).

\section{Publication bias}

Visual inspection of funnel plots suggested an asymmetry in the meta-analyses of flaxseed's effects on plasma CRP concentrations. Using a "trim and fill" method six potentially missing studies were imputed on the right side of the funnel plot (Figure 5). However, the corrected effect size remained non-significant after imputation (WMD: $-0.10 \mathrm{mg} / \mathrm{l}, 95 \% \mathrm{Cl}:-0.42,0.22)$. The results of
Egger's linear regression (intercept $=-0.86$, standard error $=0.35 ; 95 \% \mathrm{Cl}:-1.59,-0.12, t=2.44$, $\mathrm{d} f=18$, two-tailed $p=0.025$ ) but not Begg's rank correlation (Kendall's $\tau$ with continuity correction $=-0.19, z=1.20$, two-tailed $p=0.223$ ) suggested publication bias in the meta-analysis.

\section{Discussion}

This meta-analysis did not suggest a significant change in plasma CRP concentrations following supplementation with flaxseed-containing products. Subgroup analysis also did not suggest any significant difference in terms of changing plasma CRP concentrations among different types of flaxseed supplements used in the included studies, i.e. flaxseed oil, lignan extract, and ground powder.

A reason for these effects could be that flaxseed oil does not contain eicosapentaenoic acid (EPA) and docosahexaenoic acid (DHA) fatty acids, while the presence of $\alpha$-linolenic acid may not be sufficient for such beneficial effects [8]. Despite the fact that $\alpha$-linolenic acid undergoes conversions 
S. Ursoniu, A. Sahebkar, M.C. Serban, I. Pinzaru, C. Dehelean, L. Noveanu, J. Rysz, M. Banach; Lipid and Blood Pressure Meta-Analysis Collaboration (LBPMC) Group

A

Study name

Statistcs for each study

Difference in means and $95 \% \mathrm{Cl}$

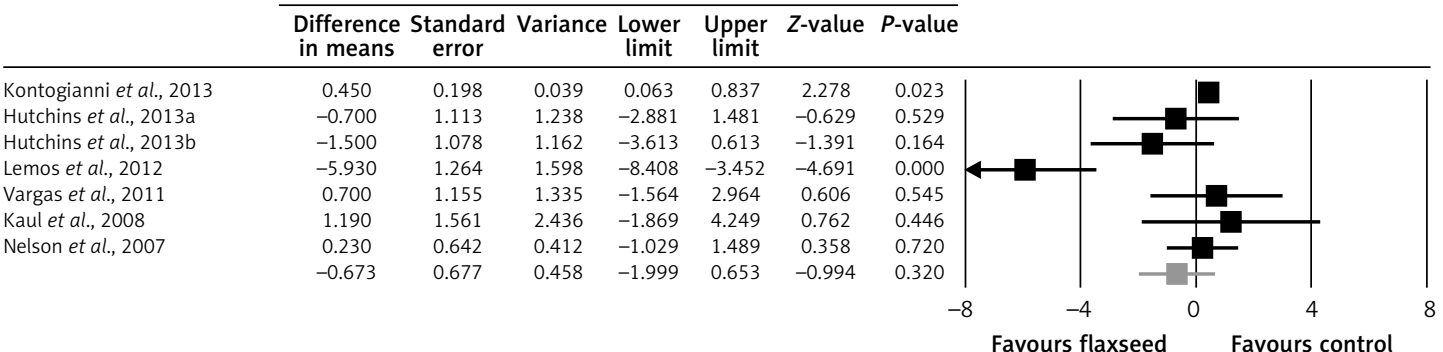

B

Study name $\quad$ Statistcs for each study

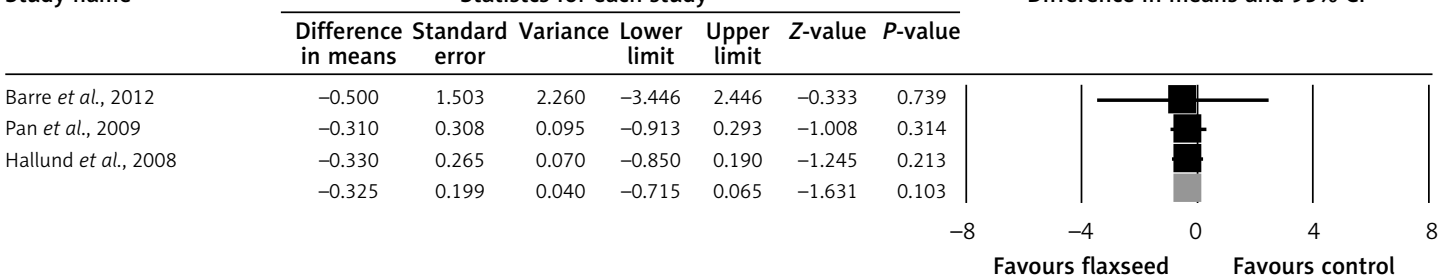

C

Study name $\quad$ Statistcs for each study

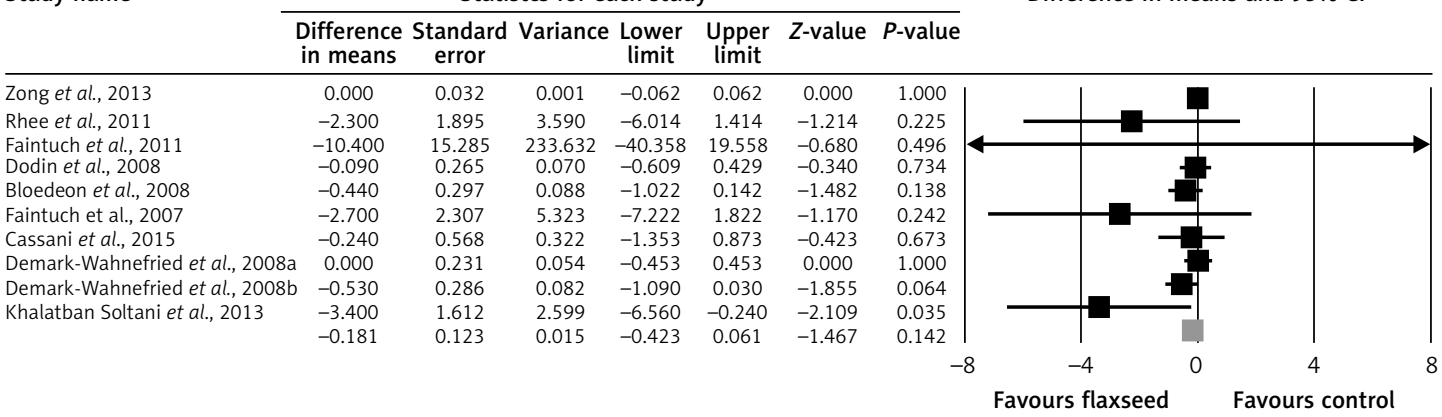

Figure 3. Forest plot displaying weighted mean difference and $95 \%$ confidence intervals for the impact of flaxseed oil (A), lignan extract (B), and ground powder (C) on plasma C-reactive protein concentrations

to longer-chain n-3 polyunsaturated fatty acids or essential fatty acids such as EPA, docosapentaenoic acid (DPA), and DHA, the exact percentage of these conversions in the cells, plasma, and tissues are still not known [37]. The $\alpha$-linolenic acid contained in flaxseed products was shown to inhibit the metabolisation of arachidonic acid to more inflammatory cytokines [38]. Furthermore, different factors such as smoking, gender, and high intake of long-chain $n-3$ polyunsaturated fatty acids were shown to affect the metabolic capacity of $\alpha$-lino- lenic acid conversions [39, 40]. It has been shown that younger women have a greater capacity of conversion of $\alpha$-linolenic acid to essential fatty acids than older women and men, due to having a hormonal profile more sensitive to diet [41]. This capacity of conversion of $\alpha$-linolenic acid to essential fatty acids is even greater during the period of pregnancy and lactation.

Another fact that may account for these results is that less than $10 \%$ of dietary $\alpha$-linolenic acid is incorporated in the plasma phospholipid pool
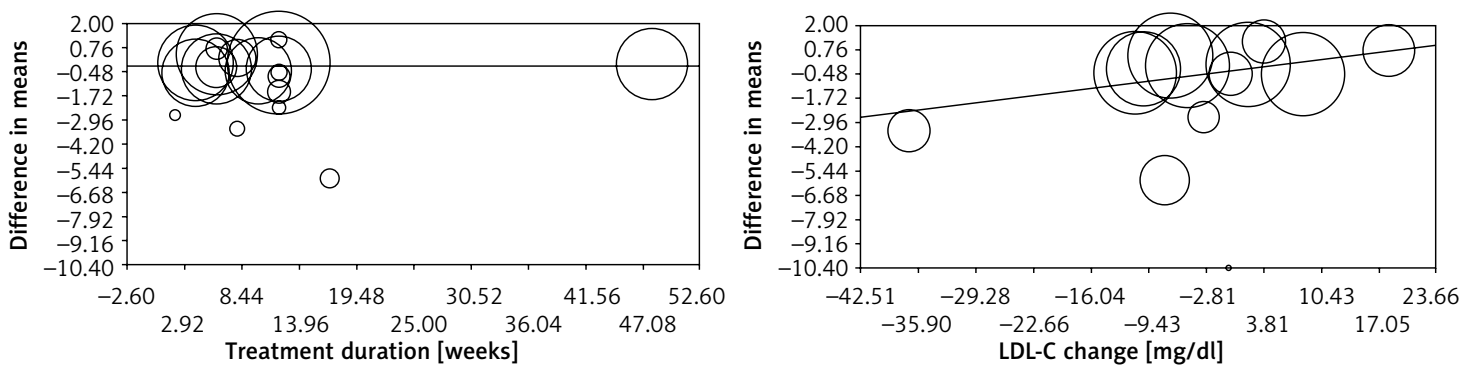

Figure 4. Meta-regression plots of the association between mean changes in plasma C-reactive protein concentrations with duration of supplementation and changes in plasma LDL-C concentrations 


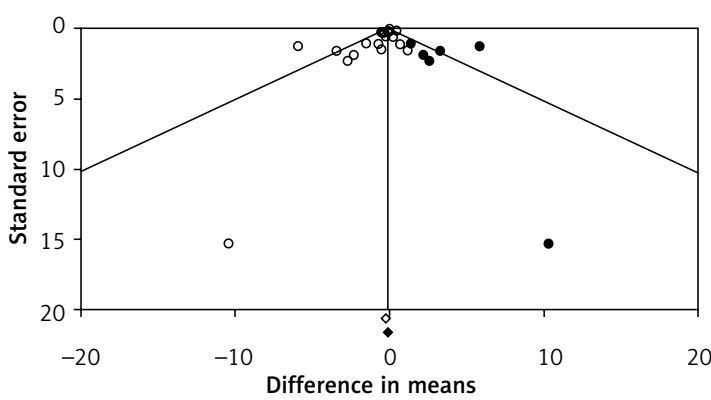

Figure 5. Funnel plot displaying publication bias in the studies reporting the impact of flaxseed supplementation on plasma C-reactive protein concentrations

[42]. Moreover, the beneficial effects of $\alpha$-linolenic acid derived from plant sources, which is less effective than omega-3 obtained from animal sources, might also influence the results on flaxseed supplements and products on plasma CRP levels.

Lignans, the precursors of enterodiol and enterolactone, are also important compounds found in flaxseed products converted by the microbial flora in the colon $[8,43]$. The administration of the principal lignan of flaxseed, secoisolariciresinol diglucoside and its primary metabolites: secoisolariciresinol (SECO), enterodiol (ED), and enterolactone (EL), on male Wistar rats, showed short half-lives, a large volume of distribution, and a high systemic clearance [44]. These pharmacokinetics properties of lignans might also explain the lack of effects of flaxseed products on plasma CRP levels. Another potential reason may lie in the fact that the effects of fatty acids on inflammatory cells are modulated by changes in fatty acid composition of cell membranes, causing lipid raft production, changes of membrane fluidity, and modifications of gene expression and of the pattern of peptide and lipid mediator production [45-50].

The present meta-analysis has some limitations. There were only a few eligible RCTs, and most of them had a small number of participants with suitable short time of supplementation, and they were heterogeneous regarding the characteristics of patients and study design. Many characteristics that vary within studies, such as the type of flaxseed products, the background of the patients included, the control groups, or the quality of the studies, could have been factors of between-study heterogeneity. Our results showed that the significance of estimated pooled effect size was not biased by any single study.

In conclusion, this meta-analysis of available randomised controlled trials does not suggest any significant benefit of flaxseed product supplementation in decreasing plasma CRP concentrations. Larger, well-designed studies with higher doses and longer follow-up should be performed to validate the current results.

\section{Acknowledgments}

The meta-analysis was prepared within the Lipid and Blood Pressure Meta-Analysis Collaboration (LBPMC) Group (www.lbpmcgroup.umed.pl).

\section{Conflict of interest}

The authors declare no conflict of interest.

\section{References}

1. Goyal A, Sharma V, Upadhyay N, Gill S, Sihag M. Flax and flaxseed oil: an ancient medicine and modern functional food. J Food Sci Technol 2014; 51: 1633-53.

2. Shim YY, Gui B, Arnison PG, Wang Y, Reaney MJT. Flaxseed (Linum usitatissimum L.) bioactive compounds and peptide nomenclature: a review. Trends Food Sci Technol 2014; 38: 5-20.

3. Zuravski L, Coelho RP, Duarte JA, et al., Protective role of golden flaxseed (Linum usitatissimum L) against oxidative damage in lipids and proteins of healthy volunteers. J Biosci Med 2015; 3: 45-53.

4. Edel AL, Rodriguez-Leyva D, Maddaford TG, et al. Dietary flaxseed independently lowers circulating cholesterol and lowers it beyond the effects of cholesterol-lowering medications alone in patients with peripheral artery disease. J Nutrition 2015; 145: 749-57.

5. Caligiuri SP, Edel AL, Aliani M, Pierce GN. Flaxseed for hypertension: implications for blood pressure regulation. Curr Hypertens Rep 2014; 16: 499.

6. Khalatbari Soltani S, Jamaluddin R, Tabibi H, et al. Effects of flaxseed consumption on systemic inflammation and serum lipid profile in hemodialysis patients with lipid abnormalities. Hemodial Int 2013; 17: 275-81.

7. Kajla P, Sharma A, Sood DR. Flaxseed - a potential functional food source. J Food Sci Technol 2015; 52: 1857-71.

8. Sahebkar A, Serban C, Ursoniu S, Banach M. Effect of garlic on plasma lipoprotein(a) concentrations: a systematic review and meta-analysis of randomized controlled clinical trials. Nutrition 2016; 32: 33-40.

9. Serban C, Sahebkar A, Antal D, Ursoniu S, Banach M. Effects of supplementation with green tea catechins on plasma C-reactive protein concentrations: a systematic review and meta-analysis of randomized controlled trials. Nutrition 2015; 31: 1061-71.

10. Serban MC, Sahebkar A, Dragan S, et al. A systematic review and meta-analysis of the impact of spirulina supplementation on plasma lipid concentrations. Clin Nutr 2016; 35: 842-51.

11. Prasad K. C-reactive protein (CRP)-lowering agents. Cardiovasc Drug Rev 2006; 24: 33-50.

12. Koenig W, Sund M, Fröhlich M, et al. C-reactive protein, a sensitive marker of inflammation, predicts future risk of coronary heart disease in initially healthy middle-aged men results from the MONICA (Monitoring Trends and Determinants in Cardiovascular Disease) Augsburg Cohort Study, 1984 to 1992. Circulation 1999; 99: 237-42.

13. Ridker PM, Hennekens CH, Buring JE, Rifai N. C-reactive protein and other markers of inflammation in the prediction of cardiovascular disease in women. N Engl J Med 2000; 342: 836-43.

14. Rhee Y, Brunt A. Flaxseed supplementation improved insulin resistance in obese glucose intolerant people: a randomized crossover design. Nutr J 2011; 10: 44.

15. Moher D, Liberati A, Tetzlaff J, Altman DG; PRISMA Group. Preferred reporting items for systematic reviews 
and meta-analyses: the PRISMA statement. BMJ 2009; 339: b2535.

16. Green S. Cochrane handbook for systematic reviews of interventions version 5.1. 0 [updated March 2011]. The Cochrane Collaboration 2011.

17. Borenstein $M$, et al. Comprehensive meta-analysis version 2. Englewood, NJ: Biostat, 2005; 104.

18. Wan X, Wang W, Liu J, Tong T. Estimating the sample mean and standard deviation from the sample size, median, range and/or interquartile range. BMC Med Res Methodol 2014; 14: 135.

19. Sutton AJ, Abrams KR, Jones DR, Sheldon TA, Song F. Methods for meta-analysis in medical research. John Wiley, New York 2000.

20. Duval S, Tweedie R. Trim and fill: a simple funnel-plotbased method of testing and adjusting for publication bias in meta-analysis. Biometrics 2000; 56: 455-63.

21. Kontogianni MD, Vlassopoulos A, Gatzieva A, et al. Flaxseed oil does not affect inflammatory markers and lipid profile compared to olive oil, in young, healthy, normal weight adults. Metabolism 2013; 62: 686-93.

22. Hutchins AM, Brown BD, Cunnane SC, Domitrovich SG, Adams ER, Bobowiec CE. Daily flaxseed consumption improves glycemic control in obese men and women with pre-diabetes: a randomized study. Nutr Res 2013; 33 : 367-75.

23. Zong G, Demark-Wahnefried W, Wu H, Lin X. Effects of flaxseed supplementation on erythrocyte fatty acids and multiple cardiometabolic biomarkers among Chinese with risk factors of metabolic syndrome. Eur J Nutr 2013; 52: 1547-51.

24. Barre DE, Mizier-Barre KA, Stelmach E, et al. Flaxseed lignan complex administration in older human type 2 diabetics manages central obesity and prothrombosis an invitation to further investigation into polypharmacy reduction. J Nutr Metabol 2012; 2012: 585170.

25. Lemos JR, Alencastro MG, Konrath AV, Cargnin M, Manfro RC. Flaxseed oil supplementation decreases C-reactive protein levels in chronic hemodialysis patients. Nutr Res 2012; 32: 921-7.

26. Rhee Y, Brunt A. Flaxseed supplementation improved insulin resistance in obese glucose intolerant people: a randomized crossover design. Nutr J 2011; 10: 44

27. Faintuch J, Bortolotto LA, Marques PC, Faintuch JJ, França J, Cecconello I. Systemic inflammation and carotid diameter in obese patients: pilot comparative study with flaxseed powder and cassava powder. Nutr Hosp 2011; 26: 208-13.

28. Pan A, Demark-Wahnefried W, Ye X, et al. Effects of a flaxseed-derived lignan supplement on C-reactive protein, IL- 6 and retinol-binding protein 4 in type 2 diabetic patients. Br J Nutr 2009; 101: 1145-9.

29. Dodin S, Cunnane SC, Mâsse B, et al. Flaxseed on cardiovascular disease markers in healthy menopausal women: a randomized, double-blind, placebo-controlled trial. Nutrition 2008; 24: 23-30.

30. Bloedon LT, Balikai S, Chittams J, et al. Flaxseed and cardiovascular risk factors: results from a double blind, randomized, controlled clinical trial. J Am Coll Nutr 2008; 27: 65-74.

31. Hallund J, Tetens I, Bügel S, Tholstrup T, Bruun JM. The effect of a lignan complex isolated from flaxseed on inflammation markers in healthy postmenopausal women. Nutr Metab Cardiovasc Dis 2008; 18: 497-502.

32. Kaul N, Kreml R, Austria JA, et al. A comparison of fish oil, flaxseed oil and hempseed oil supplementation on selected parameters of cardiovascular health in healthy volunteers. J Am Coll Nutr 2008; 27: 51-8.
33. Nelson TL, Stevens JR, Hickey MS. Inflammatory markers are not altered by an eight week dietary alpha-linolenic acid intervention in healthy abdominally obese adult males and females. Cytokine 2007; 38: 101-6.

34. Faintuch J, Horie LM, Barbeiro HV, et al. Systemic inflammation in morbidly obese subjects: response to oral supplementation with alpha-linolenic acid. Obes Surg 2007; 17: 341-7.

35. Cassani RS, Fassini PG, Silvah JH, Lima CM, Marchini JS. Impact of weight loss diet associated with flaxseed on inflammatory markers in men with cardiovascular risk factors: a clinical study. Nutr J 2015; 14: 1-8.

36. Demark-Wahnefried W, et al. Flaxseed supplementation (not dietary fat restriction) reduces prostate cancer proliferation rates in men presurgery. Cancer Epidemiol Biomarkers Prevent 2008; 17: 3577-87.

37. Burdge GC, Calder PC. Conversion of alpha-linolenic acid to longer-chain polyunsaturated fatty acids in human adults. Reprod Nutr Dev 2005; 45: 581-97.

38. James MJ, Gibson RA, Cleland LG. Dietary polyunsaturated fatty acids and inflammatory mediator production. Am J Clin Nutr 2000; 71: 343s-8s.

39. Childs CE, Kew S, Finnegan YE, et al. Increased dietary alpha-linolenic acid has sex-specific effects upon eicosapentaenoic acid status in humans: re-examination of data from a randomised, placebo-controlled, paralle study. Nutr J 2014; 13: 113

40. Marangoni F, Colombo C, De Angelis L, et al. Cigarette smoke negatively and dose-dependently affects the biosynthetic pathway of the $n-3$ polyunsaturated fatty acid series in human mammary epithelial cells. Lipids 2004; 39: 633-7.

41. Burdge GC, Calder PC. Dietary alpha-linolenic acid and health-related outcomes: a metabolic perspective. Nutr Res Rev 2006; 19: 26-52.

42. Goyens PL, Spilker ME, Zock PL, Katan MB, Mensink RP. Conversion of alpha-linolenic acid in humans is influenced by the absolute amounts of alpha-linolenic acid and linoleic acid in the diet and not by their ratio. Am J Clin Nutr 2006; 84: 44-53.

43. Ursoniu S, Sahebkar A, Andrica F, et al. Effects of flax seed supplements on blood pressure: a systematic review and meta-analysis of controlled clinical trial. Clin Nutr 2016; 35: 615-25.

44. Mukker JK, Singh RS, Muir AD, Krol ES, Alcorn J. Compar ative pharmacokinetics of purified flaxseed and associated mammalian lignans in male Wistar rats. $\mathrm{Br} \mathrm{J}$ Nutr 2015; 113: 749-57.

45. Calder PC. Fatty acids and inflammation: the cutting edge between food and pharma. Eur J Pharmacol 2011 668 Suppl 1: S50-8.

46. Sahebkar A, Serban MC, Gluba-Brzózka A, et al. Lipidmodifying effects of nutraceuticals: an evidence-based approach. Nutrition 2016; 32: 1179-92.

47. Banach M, Patti AM, Giglio RV, et al.; International Lipid Expert Panel (ILEP). The role of nutraceuticals in statin intolerant patients. J Am Coll Cardiol 2018; 72: 96-118.

48. Patti AM, Al-Rasadi K, Giglio RV, et al. Natural approaches in metabolic syndrome management. Arch Med Sci 2018; 14: 422-41.

49. Cicero AFG, Colletti A, Bajraktari G, et al. Lipid lowering nutraceuticals in clinical practice: position paper from an International Lipid Expert Panel. Arch Med Sci 2017; 13: $965-1005$

50. Soran H, Adam S, Mohammad JB, et al. Hypercholesterolaemia - practical information for non-specialists. Arch Med Sci 2018; 14: 1-21. 